\title{
Evaluation of commercial fluoride solutions on bovine enamel demineralization, using $\mathrm{pH}$-cycling model
}

\author{
Avaliação de soluções fluoretadas comerciais na redução da \\ perda mineral em esmalte bovino, utilizando modelo de \\ ciclagem de $\mathrm{pH}$
}

\begin{abstract}
Purpose: The aim of this in vitro study was to evaluate the fluoride concentration in mouthrinses and their capacity to intervene with the caries process.

Methods: The analysis of the fluoride concentration in the solutions was carried with ion specific electrode connected to an ion analyzer. Bovine incisors enamel blocks with previously known superficial microhardness were submitted to a pH cycling model and treated with fluoridated solutions, and later reanalyzed for microhardness and fluoride incorporation.

Results: The fluoride concentration (ppm) found in the solutions SANiFill- Sanikids ${ }^{\circledR}$, Colgate Plax Fresh Mint ${ }^{\circledR}$, Oral $B^{\circledR}$, Sorriso Fresh ${ }^{\circledR}$ and Cepacol ${ }^{\circledR}$ (not fluoridated) were, respectively: $242.91 \pm 21.89 ; 248.42 \pm 3.55 ; 248.29 \pm 11.31 ; 257.61 \pm 17.57$ and $35.37 \pm 10.64$. The lowest loss of superficial microhardness was observed with the use Sorriso Fresh ${ }^{\circledR}(29.66 \% \pm 8.84)$, followed by Plax Fresh mint ${ }^{\circledR}(32.99 \% \pm 14.09)$ and Oral $B^{\circledR}(43.00 \% \pm 18.34)$.

Conclusion: The data suggest that fluoride solutions, in proper concentrations, are capable of intervening on the phenomena of demineralization and remineralization, promoting fluoride incorporation and, consequently, decreasing the loss of microhardness on dental enamel.
\end{abstract}

Key words: Microhardness; fluoride; $\mathrm{pH}$-cycling

\section{Resumo}

Objetivo: $O$ objetivo deste estudo in vitro foi analisar a concentração de flúor em diferentes soluções fluoretadas para bochechos e sua capacidade de interferir no processo de cárie.

Metodologia: A análise da concentração de flúor nas soluções para bochecho foi realizada com eletrodo específico para íon flúor acoplado a um analisador de íons Orion. Blocos de esmalte de dentes incisivos bovinos com a microdureza superficial conhecida foram submetidos à ciclagem de pH e uso de soluções fluoretadas, sendo, posteriormente, avaliados por uma nova análise de microdureza e também pela incorporação de flúor.

Resultados: As concentrações de flúor (ppm) encontradas nas soluções SANiFill ${ }^{\circledR}$, Colgate ${ }^{\circledR}$ Plax $^{\circledR}$, Oral B ${ }^{\circledR}$, Sorriso ${ }^{\circledR}$ e Cepacol ${ }^{\circledR}$ (não fluoretada) foram, respectivamente: 245,94 ; 247,$61 ; 251,50 ; 258,01$ e 38,44. A menor perda de porcentagem de dureza superficial foi observada com o uso da solução fluoretada Sorriso ${ }^{\circledR}(29,7 \% \pm 14,4)$, seguida por Colgate ${ }^{\circledR}$ Plax ${ }^{\circledR}(33 \% \pm 14,1)$ e Oral $B^{\circledR}(43 \% \pm 18,3)$. Todas as soluções fluoretadas analisadas mostraram capacidade de incorporar flúor no esmalte dental.

Conclusão: Os dados sugerem que as soluções fluoretadas foram capazes de interferir nos fenômenos de desmineralização e remineralização, promover incorporação de flúor e, conseqüentemente, diminuir a perda de dureza no esmalte dental.

Palavras-chave: Microdureza; flúor; ciclagem de $\mathrm{pH}$

\author{
Maira de Souza Carvalho a \\ Juliana Maria Souza de Oliveira ${ }^{a}$ \\ Juliana Vianna Pereira ${ }^{a}$ \\ Maria Augusta Bessa Rebelo a \\ a Faculty of Dentistry, Federal University of \\ Amazonas, Manaus, AM, Brazil
}

\author{
Correspondence: \\ Maria Augusta Bessa Rebelo \\ Rua Rio Itannauá, 194/504; Nossa Sra das Graças \\ Manaus, AM - Brazil \\ 69053-040 \\ Email:augusta@ufam.edu.br
}

Received: November 24, 2008

Accepted: March 31, 2010

Conflict of Interest Statement: The authors state that there are no financial and personal conflicts of interest that could have inappropriately influenced their work.

Copyright: (c) 2010 Carvalho et al.; licensee EDIPUCRS. This is an Open Access article distributed under the terms of the Creative Commons AttributionNoncommercial-No Derivative Works 3.0 Unported License. 


\section{Introduction}

Researches on the effect of fluoride on oral health began more than 100 years ago, but it was on the second half of the 20th century that the focus of the studies was the development and evaluation of fluoride products (1). Since then, the frequent use of composites with low fluoride concentration, such as dentifrices, has shown efficiency on the control of dental caries (2), by its constant presence on the oral cavity, thus interfering on the phenomena of de- and remineralization on the interface tooth-biofilm (3).

On the other side, the use of fluoride mouthrinses has been suggested as an additional prevention method, of individual character, in terms of risk or caries activity, or may be important in a collective sense considering the prevalence of dental caries on the population, or groups epidemiologically vulnerable $(4,5)$.

In order to interfere on the dynamics of caries development, fluoride solutions must be in the adequate concentration and thus be able to react with dental tissues. In an attempt to regulate the manufacturing of such products in Brazil, the National Sanitary Surveillance System (ANVISA - Agência Nacional de Vigilância Sanitária) established, by Resolution 29 on August 2000, the concentration of fluoride in solutions at $225 \mathrm{ppm}$, with variation of $10 \%$ (6).

The purpose of this study was to evaluate the anti-caries performance of four commercial fluoride solutions available in the Brazilian market, using a $\mathrm{pH}$ cycling model and bovine enamel, through analysis of microhardness and determination of fluoride concentration on dental enamel.

\section{Methods}

\section{Experimental Design}

A blind in vitro study was carried to verify the ability of fluoride solutions to inhibit demineralization of enamel. Enamel blocks ( $4 \times 4 \mathrm{~mm}$ ) obtained from bovine incisors were polished sequentially and selected according to their surface microhardness (MSI, $n=50$ ). The blocks were submitted to $\mathrm{pH}$ cycling and treatment with fours commercial fluoride solutions and one solution without fluoride (negative control). After cycling, surface microhardness was analyzed, and both loss of surface hardness (\%PDS) and fluoride concentration on enamel $\left(\mu \mathrm{g} \mathrm{F} / \mathrm{mm}^{3}\right)$ were calculated. For data analysis, mouthrinses, and variables MSI, MSF, \%PDS and fluoride concentration on enamel $\left(\mu \mathrm{g} / \mathrm{mm}^{3}\right)$ were considered as variation factor.

\section{Fluoride concentration analysis on mouthrinses solutions}

The analyzed solutions were: SANiFill-Sani Kids ${ }^{\circledR}$ (Facilit Odontologia e Perfumaria LTDA - Rio de Janeiro, RJ, Brazil), Colgate Plax ${ }^{\circledR}$ Fresh Mint (Colgate-Palmolive Ind. e Com. LTDA - São Paulo, SP, Brazil), Oral B ${ }^{\circledR}$ (Procter \& Gamble do Brasil LTDA - São Paulo, SP, Brazil), Sorriso ${ }^{\circledR}$ Fresh (Colgate-Palmolive Ind. e Com. LTDA - São Paulo, SP, Brazil) e Cepacol ${ }^{\circledR}$ (Sanofi-Aventis Farmacêutica LTDA
- Suzano, São Paulo, Brazil), the latter is a non-fluoridated solution used as negative control. The solutions were coded as $\mathrm{S} 1, \mathrm{~S} 2, \mathrm{~S} 3, \mathrm{~S} 4, \mathrm{CN}$, respectively. Solutions, in triplicate, were numbered from 1 to $15 ; 1 \mathrm{~mL}$ of each solution was inserted with a pipette in flasks. The flask was completed with deionizer water until $100 \mathrm{~mL}$, thus obtaining three dilutions for each product (7). Previously to the analysis of the samples, a calibration curve was carried, with patterns from 0.1 to $1.0 \mathrm{ppm} \mathrm{F}^{-}$obtained from Fluoride Standard $\left(100 \mathrm{ppm} \mathrm{F}^{-}\right)$- Orion Ion Plus ${ }^{\circledR}$ (Thermo Fisher Scientific Inc. - Waltham, MA, USA). The fluoride in the solutions was determined by mixing $1 \mathrm{~mL}$ of the diluted samples with $1 \mathrm{~mL}$ of TISAB II (acetate buffer at $0.75 \mathrm{M}, \mathrm{pH} 5.0, \mathrm{NaCl}$ 1.0 $\mathrm{M}$ and CDTA 0,4\%), under agitation. Fluoride analysis was performed using a specific electrode for ions Fluoride (Orion 96-09 - Orion Research Inc. - Boston, MA, USA) connected to an ion analyzer (Orion 720-A - Orion Research Inc. - Boston, MA, USA).

\section{Preparation of dental blocks and determination of enamel surface microhardness}

Fifty enamel blocks $(4 \times 4 \mathrm{~mm})$ were prepared from bovine incisors. The enamel surface was ground flat with abrasive papers 600 and 1200 grit under water and polished with felt paper wet by diamond suspension (Diamond Suspension 1 Micron - Water Base $n^{\circ} 406530$ - Buehler ${ }^{\circledR}$ Metadi $^{\circledR}$, Lake Bluff, IL, USA).

Initial surface microhardness (MSI) of the enamel block was measured with a microhardness tester (Shimadzu HMV2000 - Shimadzu Corporation, Japan) with Knoop indenter. A referential indentation on the base line was created using a $100 \mathrm{~g}$ weight for 5 seconds. In addition, five indentations with $100 \mu \mathrm{m}$ space from each other were prepared using a $50 \mathrm{~g}$ weight for 5 seconds, and from these, an average in Knoop (KHN) was obtained (8). Only blocks with average surface hardness $340 \mathrm{KHN}(9)( \pm 10 \%$, between 316 and $374 \mathrm{KHN}$ ) were used, and those samples were randomly assigned into 5 groups.

\section{$\mathrm{pH}$ cycling and treatments}

The enamel blocks were submitted to $\mathrm{pH}$ cycling for 5 days, simulating high caries challenge, according to Featherstone et al. (10). The groups of blocks were kept in $50 \mathrm{ml}$ of demineralizing solution with $\mathrm{pH} 4.3(2.0 \mathrm{mM}$ calcium, $2.0 \mathrm{mM}$ phosphate in acetate buffer $0.075 \mathrm{M}$ ) at $37^{\circ} \mathrm{C}$ for 3 hours; and in $50 \mathrm{~mL}$ remineralizing solution with $\mathrm{pH}$ $7.0\left(1.5 \mathrm{mM} \mathrm{Ca}, 0.9 \mathrm{mM} \mathrm{PO}_{4}^{3}, 150 \mathrm{mM} \mathrm{KCl}\right.$ in Tris buffer $0.1 \mathrm{M})$ at $37^{\circ} \mathrm{C}$ for 20 hours (11).

During $\mathrm{pH}$ cycle, the enamel blocks were treated twice a day for one minute with $50 \mathrm{~mL}$ of the solutions in analysis (before and after demineralization cycle). The negative control group was treated with a non-fluoridated solution and the remaining groups with the experimental fluoride solutions $(0.05 \% \mathrm{NaF})$. After 5 -day cycle, the blocks were immersed for 48 hours in remineralizing solution and then the superficial microhardness was reevaluated, as well as the presence of fluoride on enamel. 


\section{Post-treatment microhardness analysis of} enamel surface

After $\mathrm{pH}$ cycling, MSF of enamel block was again measured; ten indentation ( 5 above and 5 below base line) were created and a new average value (KHN) was found, and the percentage of surface hardness loss was calculated [\%PDS=100 (MSF - MSI)/MSI].

\section{Determination of fluoride concentration on enamel}

Dental blocks were protected by acid-resistant varnish, allowing only the enamel surface free. Then, a layer of enamel was removed from each block by immersion in $0.5 \mathrm{~mL}$ of $\mathrm{HCl}$ at $0.5 \mathrm{M}$ for 30 seconds under agitation (12). An equal volume of TISAB II (pH 5.0), modified with $\mathrm{NaOH}$ at $20 \mathrm{~g} / \mathrm{L}$, was added to each flask to neutralize the reaction. Fluoride measurements were carried using and specific fluoride electrode and ion analyzer, previously calibrated with standard fluoride solutions from 0.1 to $1.0 \mathrm{ppm} \mathrm{F}^{-}$. The width of the removed enamel layer was calculated from the concentration of inorganic phosphorus, determined by colorimetric method of Fiske and Subarrow (13); rate of phosphorus on enamel of $17.4 \%$ and density 2.92 were considered (9).

\section{Statistical analysis}

Statistical analysis was performed using the software EpiInfo 3.5.1 for Windows, with significance level of 5\%. Data were submitted to normality and homogeneity tests, Shapiro-Wilk's and Barltlett's, respectively. Variables MSI, MSF, \%PDS and $\mu \mathrm{g} \mathrm{F} / \mathrm{mm}^{3}$ showed heterogeneity and were submitted to Kruskal-Wallis test followed by Mann-Whitney test for two-tailed comparison $(14,15)$.

\section{Results}

Fluoride concentration on solutions showed superior values to those related by the manufacturer (Table 1). Table 2 shows that after demineralization-remineralization and use of solutions all groups presented loss of superficial hardness and differed significantly $(P<0.001)$ from control group. Highest and lowest losses of hardness were observed with solutions S1 and S4, respectively (Table 2). Regarding fluoride present on

Table 1. Concentration (Mean $\pm S D ; n=10$ ) of fluoride $(F)$ on mouthrinses solutions (as displayed on packaging) and present on enamel after $\mathrm{pH}$ cycling.

\begin{tabular}{ccc}
\hline \multirow{2}{*}{ Groups } & \multicolumn{2}{c}{ Analysis } \\
\cline { 2 - 3 } & ppm F on solutions & $\mu \mathrm{g} \mathrm{F} / \mathrm{mm}^{3}$ on ename $^{*}$ \\
\hline S1 & $242.91 \pm 21.89(226)$ & $11424.64 \pm 2273.46^{a}$ \\
S2 & $248.42 \pm 3.55(225)$ & $12595.58 \pm 6823.82^{a}$ \\
S3 & $248.29 \pm 11.31(226)$ & $9226.56 \pm 2009.99^{a}$ \\
S4 & $257.61 \pm 17.57(225)$ & $9303.27 \pm 2373.27^{a}$ \\
CN & $35.37 \pm 10.64$ (not shown) & $96.85 \pm 48.66^{b}$ \\
\hline
\end{tabular}

$*$ Different letters indicate statistical difference between groups for each analysis (Kruskal-Wallis, $P<0.001$ ). enamel, all groups presented statistically significant difference $(P<0.001)$ when compared to control group (Table 1).

\section{Discussion}

The use of fluoridated mouthrinses represents yet another alternative to maintain fluoride in the oral cavity and interfere on the dynamics of caries development. The sinequa-non condition for commercial products to have anticaries potential is that they should present a significant concentration of soluble fluoride. The results obtained in this study show that the analyzed solution are above the values specified by the manufacturer. Solutions S1 and S2 presented values according to Resolution 29 of ANVISA (6), which establishes a $225 \mathrm{ppm}$ fluoride concentration, with $10 \%$ variation. Solutions S3 and S4 presented value above that specified by ANVISA. The concentration specified by the resolution is coherent to the values stated by literature as efficient; the results of several studies support the concept that the frequent use of relatively low concentration fluoride would be the most appropriate way to control the development of dental caries (16). Therefore, the solutions tested that presented fluoride concentration around $225 \mathrm{ppm}$ can, regarding the dose prescribed, potentially present efficiency if used on the recommended frequency and for an adequate period of time.

The results of enamel surface microhardness analysis showed that fluoridated solutions were capable of reducing mineral loss, even during cariogenic challenging situations ( $\mathrm{pH}$ cycling), when compared to a non-fluoridated solution $(\mathrm{CN})$, which is in agreement to developed studies with similar methodology (17). The differences found on percentage of hardness loss (\%PDS) from S1 to S2 and S4, may be related to other components not evaluated in this study; although this has not been observed in other study (18) that evaluated whether the presence of composite cetylpyridinium chloride (antiseptic) would reduce the effect of fluoride on caries development. The results obtained in the present study confirm the action of fluoride on dynamic development of caries, resulting from unbalance between phenomenon of de- and remineralization of hard dental tissues $(19,20)$.
Table 2. Values (Mean $\pm S D, n=10$ ) of microhardness (Knoop) of surface (MSI and MSF) before and after $\mathrm{pH}$ cycling, according to analysis and groups.

\begin{tabular}{cccc}
\hline \multirow{2}{*}{ Groups } & \multicolumn{3}{c}{ Analysis } \\
\cline { 2 - 4 } & MSI & MSF* $^{*}$ & \multicolumn{1}{c}{ \%PDS* $^{*}{ }^{\mathrm{a}}$} \\
\hline S1 & $351.7 \pm 18.29$ & $168.6 \pm 54.95^{a}$ & $52.41 \pm 4.38^{\circ}$ \\
S2 & $347.5 \pm 17.04$ & $232.8 \pm 49.04^{\mathrm{b}}$ & $32.99 \pm 14.09^{\mathrm{b}}$ \\
S3 & $352.9 \pm 16.43$ & $200.5 \pm 64.76^{\mathrm{a}, \mathrm{b}}$ & $43.00 \pm 18.34^{\mathrm{a}, \mathrm{b}}$ \\
S4 & $348.3 \pm 23.70$ & $246.4 \pm 43.76^{\mathrm{b}}$ & $29.66 \pm 8.84^{\mathrm{b}}$ \\
CN & $311.6 \pm 90.18$ & $27.0 \pm 19.53^{\mathrm{c}}$ & $89.61 \pm 8.71^{\mathrm{c}}$ \\
\hline
\end{tabular}

* Different letters indicate statistical difference between groups for each analysis (Kruskal-Wallis, $P<0.001$ ). 
Fluoride concentration on sound enamel is generally between 20 and $100 \mathrm{ppm}$, depending on fluoride ingestion during dental development, however the mineral incorporated to the tooth is insufficient to alter enamel solubility facing $\mathrm{pH}$ variation (21); only when fluoride is incorporated to a new crystal formed on the surface during remineralization a higher resistance to acid attack is observed $(21,22)$. The present results show that all solutions testes have ability to incorporate fluoride on dental enamel, with concentration significantly higher than the non-fluoride solution, which strongly suggests its influence on lessening the loss of hardness, corroborating with previous studies $(19,22,24)$.

\section{Conclusions}

The analyzed fluoride solutions, when in adequate concentration, showed not only the capacity of incorporating fluoride on dental enamel, as well as of interfering on the dynamics of development of dental caries, reducing demineralization and activating remineralization of dental enamel.

\section{Acknowledgments}

The authors would like to thank CNPq for the Research Grant PIBIC (PIB-S-044/2006) from the Federal University of Amazonas, Brazil.

\section{References}

1. Petersen PE, Lennon MA. Effective use of fluorides for the prevention on dental caries in the 21 st century: the WHO approach. Community Dent Oral Epidemiol 2004;32:319-21.

2. Marinho VC, Higgins JP, Logan S, Sheiham A. Fluoride toothpastes for preventing dental caries in children and adolescents. Cochrane Database Syst Rev In: The Cochrane Library, Issue 1, Art. No. CD002278, 2010.

3. Cury JA, Tenuta LM. How to maintain a cariostatic fluoride concentration in the oral environment. Adv Dent Res 2008; 20:13-6.

4. Cury JA. Uso do flúor e controle da cárie como doença. In: Baratieri LN. Odontologia restauradora: fundamentos e possibilidades. São Paulo: Santos; 2001. p. 33-68.

5. Marinho VC, Higgins JP, Logan S, Sheiham A. Fluoride mouthrinses for preventing dental caries in children and adolescents. Cochrane Database Syst Rev In: The Cochrane Library, Issue 3, Art. No. CD002284, 2009.

6. Brasil. Portaria No. 29 de 28 de agosto de 2000. Diário Oficial da República Federativa do Brasil. 31 ago 2000;169:1415-537.

7. Delbem ACB, Sassaki KT, Castro AM, Pinto LMCP, Bergamaschi $\mathrm{M}$. Assessment of the fluoride concentratin and $\mathrm{pH}$ in different mouthrinses on the brazilian market. J Appl Oral Sci 2003;11: 319-23.

8. Cury JA, Rebelo MA, Del Bel Cury AA, Derbyshire MT, Tabchoury CP. Biochemical composition and cariogenicity of dental plaque formed in the presence of sucrose or glucose and fructose. Caries Res 2000;34:491-7.

9. Lazzari EP. Dental Biochemistry. 2nd $e d$. Londres: Lea \& Febiger, 1976

10. Featherstone JDB, O'Reilly MM, Shariati M, Brugler S. Enhacement of remineralization in vitro and in vivo. In: Leach SA. Factors relating to demineralization and remineralization of the teeth. Oxford: IRL Press; 1986, p. 23-34.

11. Argenta RM, Tabchoury CP, Cury JA. A modified pH-cycling model to evaluate fluoride effect on enamel demineralization. Pesqui Odontol Bras 2003;3:241-6.
12. Tenuta LM, Cerezetti RV, Del Bel Cury AA, Tabchoury CP, Cury JA. Fluoride release from CaF2 and enamel demineralization. J Dent Res 2008;87:1032-6.

13. Fiske $\mathrm{CH}$, Subarrow $\mathrm{Y}$. The colorimetric determination of phosphorous. J Biol Chem 1925;66:375-400.

14. Vieira S. Bioestatística: tópicos avançados. $2^{\text {nd }}$ ed. Rio de Janeiro: Elservier; 2004.

15. Arango HG. Bioestatística: teórica e computacional. Rio de Janeiro: Guanabara Koogan, 2001.

16. Fejerskov $O$, Thylstrup A, Larsen MJ. Rational use of fluorides in caries prevention: a concept based on possible cariostatic mechanisms. Acta Odontol Scand 1981;39:241-9.

17. Arthur RA, Giancristófaro M, Tabchoury CPM, Cury JA. In vitro study of dose-response relationship of fluoride with dental enamel. Rev odonto Ciênc 2007;22:10-4

18. Moi GP, Tenuta LM, Cury JA. Anticaries potential of a fluoride mouthrinse evaluated in vitro by validated protocols. Braz Dent J 2008;19:91-6.

19. Zero DT, Zhang JZ, Harper DS, Wu M, Kelly S, Waskow J, Hoffman $M$. The remineralizing effect of an essential oil fluoride mouthrinse in an intraoral caries test. J Am Dent Assoc 2004;135:231 -7.

20. Yu D, Sipos T, Wu MM, Bilbault T, Lynch MC, Naleway C. Effect of fluoride/essential oils-containing mouthrinse on the microhardness of demineralized bovine enamel. Am J Dent 2004;17:216-8.

21. Featherstone JD. Prevention and reversal of dental caries: role of low level fluoride. Community Dent Oral Epidemiol 1999;27:31-40.

22. Inaba D, Kawasaki K, lijima Y, Taguchi N, Hayashida H, Yoshikawa T, Furugen R, Fukumoto E, Nishivama T, Tanaka K, Takagi $O$. Enamel fluoride uptake from mouthrinse solutions with different $\mathrm{NaF}$ concentrations. Community Dent Oral Epidemiol 2002;30:248-53.

23. Zero DT. Dentifrices, mouthwashes, and remineralization/caries arrestment strategies. BMC Oral Health 2006;6:Suppl I:S9

24. Nelson DG, Coote GE, Shariati M, Featherstone JD. High resolution fluoride profiles of artificial in vitro lesions treated with fluoride dentifrices and mouthrinses during $\mathrm{pH}$ cycling conditions. Caries Res 1992;26:254-62. 